\title{
The Changeless Core in a Changing Business Environment
}

\author{
Alex Tun-Lee, Foo, Pei-Yew, Mah *, Annie Cheng-San, Ng \& Johnn-Yee, Choy \\ Faculty of Business and Finance, Universiti Tunku Abdul Rahman, Kampar, Perak, \\ Malaysia
}

Received: 23/2/2020 Revised: 10/5/2020 Accepted: 17/6/2020 Published:30/6/2020

\begin{abstract}
Rapid change in business environment poses threat to business survival. It is crucial to examine the core of business sustainability. This paper proposes changeless factors in response to today's business environment. Specifically, it addresses (1) the people factor (2) the purpose factor and (3) the principle factor as the pillars through which an organization finds its stability in the sea of business change. This paper demonstrates the unchanged factors to ensure business sustainability and to achieve long term objectives. After mapping the conceptual model, the paper devotes particular attention to conceptualizing the changeless cores of business. This research contributes practical insights for managers to further understand the cores of business sustainability. Specifically, it will assist managers to have clear goals in making decisions and managing change to enhance competitiveness in the business environment.
\end{abstract}

Keywords: Business sustainability, organizational principle, business survival

\subsection{Introduction}

Change is inevitable in today's age of rapid information dissemination. Terms like responsive organization (Skyrme, 1994; Sun et al., 2017), agile management (Shim \& Lee, 2019; Wells, 2014), organization adaptability (Stewart et al., 2003) have since surfaced in the literature to address this challenge. The current COVID-19 pandemic has caused massive change and impacted every business. It requires the business organizations to rapidly respond, adapt to changes and re-emerge in a position of strength (Craven, Mysore, Singhal, \& Wilson, 2020). If change is constant in the game of business, there should be a mechanism to capture changing variables and incorporate it into the decision support system of an organization. Businesses that refuse to change will find it difficult to survive. In the words of Drucker, the focus is not the waves in front of us but the way we react to it (Drucker, 2014). An example to explain the

* Corresponding Author

Email: mahpy@utar.edu.my, alexfoo@utar.edu.my, ncsan@utar.edu.my, choyjy@utar.edu.my 
change is the shift in consumer's preference from brick-and-mortar shopping to online shopping which has led to tremendous impact on the survival of brick-and-mortar retail players that lack online platforms. Consumer's convenience in accessing products online has an influence on retail bottom line (Floyd et al., 2014; Yang et al., 2020). Failure to keep up the game of change might translate to obsolescence, losing market share and eroding profit margin. Other examples of changes such as transformation of technological advancement from keypad input to touchscreen in smartphone industry, the pervasiveness of cloud computing and social media presence require organizations to reinvent themselves.

From a psychological perspective, human beings generally resist change (Thakur \& Srivastave, 2018). Change forces its targets to react. According to Bracha et al. (2004), it triggers fight-or-flight and anxiety related emotional responses. Yet, refusal to change maybe a costly option. This is true in the business arena where each player strives to have a competitive edge in the market. This apparent inconsistency - human tendency to refuse to change versus business need for change - presents an interesting challenge to scholars and practitioners. "Is change always the best move?"

"What yesterday's logic are we employing today with reference to the challenges of change?”(Drucker, 2014).

To answer the question, this study made several observations in the area of business sustainability. They are: (1) organization thrives best with the right people, often times the same group of people; (2) an organization is an entity with identity, and such identity provides stability in the midst of change; and (3) business success correlates well with enduring, timeless principles. Specifically, this paper proposes three changeless cores that an organization should seek to strengthen in the face of inevitable change. They are: the people factor, the purpose factor and the principle factor. They are 'changeless' in the sense that these factors provide stability to the organizations. To constantly change the people, the purpose (goal) and adopting/breaking principles will likely reduce organization's ability to face business change. The three changeless factors were thus suggested in response to the need to improve business stability. The literature on these three factors and a proposed conceptual model are discussed throughout the remainder of this paper.

\subsection{Literature Review}

Addressing business change requires a context. In this paper, three management theories (Porter's Five Forces, Value Chain, \& Balanced Scorecard) are used as the groundwork to spearhead a perspective on changeless cores that promote business survival. Three management theories were used to illustrate how business change can affect vital parts of organization. This in turn facilitates the discussion on business change. Instead 
of elaborating on every possible business change, which can be very wide in scope (customer, supplier, internal employee, policies etc), the three theories provide a scope within which business change can be discussed. They are significant in the sense that these three theories constitute the core of competitive advantage literature (Five Forces and Value Chain), as well as Balanced Scorecard that is often used as a tool in measuring competitive advantage (CA) too. CA implies organization's ability to outperform its peers, exhibit characteristic of a stable organization while navigating business change. We believe that these theories will be suitable for discussion on business stability.

The three theories provide the necessary context to appreciate the scope of changes to be expected in a business. Porter's Five Forces analyzes the threat from new entrants, pressure from suppliers and customers and the threat of substitute's products and services that can affect a business' ability to generate revenue (Porter, 2008). Value Chain Analysis encompasses primary business activities from inbound logistics, operations, outbound logistics, marketing and sales and customer service (Porter, 1985). Balanced Scorecard breakdowns a company's visions and missions to include financial, customer, internal business processes and organizational learning dimensions (Kaplan \& Norton, 1996). Overall, changes from internal (ability to innovate, organizational learning, goal alignment) and external (competitor analysis, customer service, supplier engagement) are important facets to be addressed. Instead of pursuing how each business segment should handle uncertainty, this study proposes three changeless cores that ensure stability in facing changes. The three cores drawn from observations are: the people factor the purpose (goal) factor and the principle factor. These changeless cores, though not explicitly mentioned in past literature, arise as a result of authors' observation (i.e., possessing these cores are beneficial to organizations). Additionally, while most literature were attributed to how organizations should react to changes, little effort is dedicated to identification of 'changeless factors'. This paper attempts to advance this goal, albeit at a conceptual stage at this point.

\subsection{The People Factor}

An organization is a sum of individuals when distilled to its basic core. Without the individuals, the organization is lifeless and not able to respond to stimuli. People factor is emphasized on the human resource policies and quality. It focuses on all stakeholders including employees, customers, suppliers, investors, shareholders and management who are interlinked in the business environment. These people need to learn how to react to change and take decisions to incorporate the sustainability approach in their business model. Thus, it is crucial that the people factor is emphasized when business change is to be addressed (Aguilar, Morales, Portilla, \& Hidalgo, 2019).

In his book 'Good to Great', Jim Collins illustrated lasting business with the analogy of a bus. The key is to have the right people on the right seat of the bus while also 
getting the wrong people off the bus (Collins, 2011). The idea is the thoughtful process of assigning suitable candidates to each critical component of a firm and let them run. People with the right skills on the right tasks will yield significant results thereby generating an edge over competitors. Finnie and Abraham (2002) recalled Jim Collin's idea of selecting the right people for the right task using the bus seat analogy in business setting. Collin's work is mainly on business audience and traces of academic literature were in the form of popular books, particularly Good to Great (Collins, 2011). This creates a potential gap of knowledge as the academic literature can make use of Collin's business evidence to construct research model of business survival. Recent studies acknowledging the people factor in the area of servant leadership (Reid III, 2017), human resource recruitment (Russell \& Brannan, 2016), academic employment (Barrick, 2017) and team building (Beauchamp et al., 2017) support this position.

The people factor also stresses the importance of having dynamic people, especially those of the upper, strategic management level. Business success is enabled by the resilience of its leader, oftentimes, the founder. The world identifies successful companies with their founders/CEOs. Steve Jobs of Apple, Mark Zuckerberg of Facebook, Larry Page of Google, Jeff Bezos of Amazon, to name a few, had their personal and organizational identity mostly inseparable due to their roles as the founder-leader. Extant literature in business sustainability gives attention to the people factor. Pfeffer and Veiga (1999), for example, found that people as organizational assets help in generating enduring competitive advantage. People are the engine in sustaining business and driving growth. Benefit is substantial when the people asset is taken care of (both management and the employees). People play a vital role for the organization to initiate, attract and nurture long-lasting relationships. Thus, these relationships ensure competitive advantage and improve organizational performance (Gholami et al., 2020).

The responsiveness of people as a whole is manifested in organizational agility. A study on how information technology assist in executing business strategy emphasizes the importance of organizational agility. In the authors' words:

"Faced with rapid and often unanticipated change, agility, defined as the ability to detect and respond to opportunities and threats with ease, speed, and dexterity, has emerged... as a key business imperative”

(As cited in Tallon \& Pinsonneault, 2011, p. 464)

Studies related to organizational change can also shed light in this area. For instance, Agocs (1997) in investigating organization's refusal to change has classified several types of resistance: denial, inaction and repression. Not only is change resisted, some go further to create policies that resist change initiatives in the organization. Those red tapes effectively cripple their people's response to change. Realizing the importance 
of being agile as an organization, it is vital that the organization champions initiatives that help to foster a spirit of continuous improvement and responsiveness. If there is ever a yesterday's logic in dealing with change, heavy rules and formalities are one of them. Particularly, agility of an organization assists in continuous improvement and long term commitment in performing regularly scheduled tasks (Melnyk et al., 1998 \& Unhelkar, 2016). An organizational culture that welcomes change, such as kaizen, should be advocated. In summary, the people factor is elaborated in three facets: leader's resilience, people as a core asset and organizational policy that is friendly towards change.

\subsection{The Purpose Factor (or the Goal Factor)}

From an organizational standpoint, having goal-oriented mindset helps behavioral change towards a certain direction. Without a definite goal, an organization becomes an entity with no identity, purpose and direction. Likewise, an organization that is constantly reacting to change while forgetting its purpose of existence risks losing its identity down the road. Organizational vision and mission play the important role of communicating its common goal. Formulating vision and mission statements in an expressly written form is one of the crucial requirement of a purposeful organization (Campbell \& Yeung, 1991). It provides meaning, purpose and direction. In a greater sense, it justifies the existence of the organization. It states the main activity it seeks to pursue and promote. Lastly, it provides a scope and boundary so that available resources may be channeled for maximum effectiveness in achieving that goal. The goal factor acts as one of the cores on which an organization revolves in every wind of change.

Holloman et al. (2007) discussed how a purpose-driven leadership style can sustain the vitality of an organization. Goal setting and goal clarity serve as organizational motivation, enable better performance and create commitment (Arvey et al., 1976; Lunenberg, 2011). Expressly written vision and mission statements, when communicated clearly, help companies to stay focused (Papulova, 2014), smoothen the production process (Joachim, 2010) and serve as a good heuristic (Taiwo et al., 2018). Taiwo et al. (2018) recommended meaningful, periodically updated vision statements together with assessment of compliance and contribution to such objectives. It should be noted that the organizational vision and missions, the goal-setting behavior and the strength to see it through are important facets of this second changeless core. However, some revision may be done in response to the changing business environment. In most cases, the strategic goal can be maintained while reviewing immediate and mediumterm goals.

Vision and mission as the core for every business reflecting success or failure and it is undeniable key concepts for every business (Bratianu \& Balanescu, 2008). The vision and mission statements should capture the enduring business principles (Bolland, 
2017). Vision is a strong integrator for business that allows employees to share and present the same image of the business and transform its vision into reality. A business mission clearly demonstrate its uniqueness and differentiate it from other businesses (Bratianu \& Balanescu, 2008). Amendment to these statements is not to be carried out needlessly because the overall goal is only attainable after many years. Changing the vision and mission statements too often will likely signal an erratic behavior that easily succumb to the wind of change. In conclusion, change in vision and mission lead to new opportunities and possibilities in business strategic perspective (Papulova, 2014).

\subsection{The Principle Factor}

A society cannot function if its members do not adhere to its laid down principles. Whether it is a corporate body, nation or even family, people come together while unanimously agreeing to operate on some principles (Fiske, 1992; Erdogan, Rondi, De Massis, 2020). Exactly what are these principles? The word 'principle' first surfaced in the late 14th century. It carries the meaning of origin, source, beginning, rule of conduct, axiom and basic assumption (Rudani, 2020). Late Stephen Covey is best known of his teaching on applying timeless principles for personal effectiveness, particularly his seven habits series (Covey, 1992). Principles are axioms, i.e., they are self-evidently true. They are self-authenticating and generally accepted. These principles rarely change, if ever.

Because of its unchanging nature, it is an important changeless core that an organization should possess. Principles such as reciprocity, fairness, trust, honesty, integrity are some examples applicable in business setting. It entails components of principles which interrelated and interconnected in overall business setting (Anser et al., 2020). Business engages in fair trade (Zhang \& Liu, 2020). Suppliers provide the stock to the manufacturers on credit. Returning customers purchase products that add value to their lives. A business makes a win-win deal with another party. Integrity with key stakeholders often leads to long term, profitable relationships (Cosenz, Rodrigues \& Rosati, 2020). Employee empowerment instills mutual trust, and thereby produces greater performance as a team. Particularly, integrating direct and indirect stakeholders into business are the main elements in strategic direction for an organization in enabling positive change (Hadje, 2020). Network resources help in gaining mutual benefits through shared expertise and knowledge (Cenamor et al., 2019; Partenan et al., 2019). Nevertheless, business competitive positioning is the key in achieving long term goals through facilitating innovation, consistency in improving products and services (Anser et al., 2020; Kim et al., 2008).

Extant literature on how principles play a part in organizational survival is often found in the form of 'principle-centered leadership'. Principles require thoughtful execution from the strategic level management of the organization. This is perhaps why discussion on principles will eventually lead to discussion on leadership style. 
Bandsuch et al. (2008), for example, in a discussion centered on trust, emphasizes the usefulness of principle-centered leadership in strengthening the relationship among the key business stakeholders. Specifically, trust is the product of strong leadership that is aligned with timeless principles. Another study by Edgeman (1998) examined the recipe for successful leadership with the alignment to core values. When coupled with competencies and trust, the result is strengthening core values, which includes employee empowerment.

Other than leadership, a variation of principle-based ideology can be found in the form of corporate governance (Reddy \& Sharma, 2014), regulation (Demortain, 2012), social sustainability (Missimier et al. 2017), accounting standard (Dennis, 2008; Wells, 2011), ethics (Knapp \& VandeCreek, 2007) and teaching methodology (Hong \& Sullivan, 2009). Advocating for principle-led behaviour can result in positive outcomes as it reduces tendencies for individuals to deviate from organizational norms. Principle is seen as a changeless catalyst which stabilizes employee morale as the business sails through uncertain change. Literature on organizational wisdom sometimes intersects with principle-based management. The literature emphasizes the need for individuals to uphold their integrity when carrying out tasks (McKenna et al., 2009) and behave in line with principles. For example, Ardelt (2004) discussed how wisdom can be incorporated as part of expert knowledge system within an organization. The proposition that these changeless principles can contribute to better business arises as a result of logical deduction and based on the favourable impact of principles in attaining organizational goal.

\subsection{Proposed Conceptual Model}

The paper proposed three changeless cores required in an organization in the face of rapid change. The idea of seeking for stability is an adaptation of Covey's principlecentered philosophy. Since organization is the sum of individuals, there is a reasonable ground to believe the spillover effect from personal to organizational context.

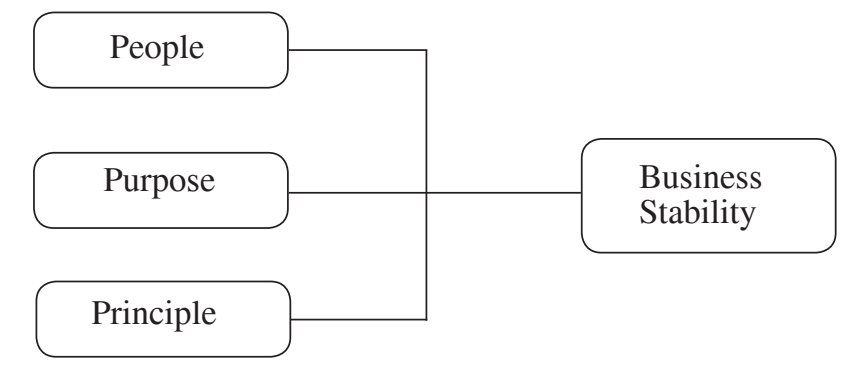

Figure 1: Conceptual Model 
Figure 1 above displays the three cores as a means of ensuring business stability. The basic assumption is that a business in its irreducible minimum should have at least these three aspects as the bedrock of business identity and survival. It provides a context where an organization knows its stand in the face of constant change in the business environment. Based on the literature review, three general propositions were created, i.e., the people factor, the purpose factor, and the principle factor serving as three changeless pillars that can lead to business success.

A simulation of the proposed model will unfold as follows: A company is setup with expressly written vision and mission statements. These statements tap on enduring principles and core values that govern individual, corporate, customers, suppliers, and competitors' behavior. Such a company is said to be built on the rock of principle, a good start in the face of change. The people serve as the important engine through which an organization becomes alive and interact in the business world. People influenced by principle-centered leadership permeate its organizational culture with principle-led behaviors. Goals that were set by the people, in the context of maintaining fidelity to enduring principles, empower them to commit to their purpose and target. When things start to go wrong, the organization go back to the drawing board of principles which is manifested in their vision and mission statements. Appropriate measures are taken in response to such disruption. The end result is an organization that is committed to its changing surrounding without compromising its purpose and principle.

\subsubsection{People and Business Stability}

Getting the right people with the right skills on the right seats (i.e., job responsibilities that are in line with their ability to contribute) help companies to function effectively. Immediate benefit includes the reduction of costs associated with staff hiring, retraining and retrenchment, improved efficiency according to the learning curve theory and foster a culture of resilience in which the same group of people will stay on for the next challenging tasks. High personnel turnover rate, on the other hand, reverses these benefits, albeit with the advantage of introducing new talents into the existing pool of manpower.

\subsubsection{Purpose and Business Stability}

While the use of vision and mission statements are already in place in most organizations, having the right focus and getting the message across all levels of management is essential. Goal clarity communicated in the form of annual board address to employees, together with alignment of staff appraisal in accordance with key performance indicators set out as per company strategic objectives can help a company to find its purpose. Such focus diminishes the effect of uncertain changes which can paralyze the company. The recent sweeping effect of COVID-19 sees some global organizations taking drastic 
measures (San Juan, 2020). For example, plunging oil price led Royal Dutch Shell to cut its dividend for the first time since World War 2 (Khazanov, Medved, Young \& Homes, 2019). Berkshire Hathaway ditching its airline investment just a month after renewing its commitment (Hariri, 2020) and Disney raising more debts as it struggles to reopen its theme parks (Gottdiener, 2020). While change is the word of the day, companies changeless purpose to protect its shareholder's value should be maintained.

\subsubsection{Principle and Business Stability}

Companies that champion honesty, integrity, truthfulness, reciprocity and a sense of duty will likely to be rewarded compared to those that violate these principles. Court cases triggered as a result of alleged infringement of copyrights and patents will cast doubt among the investing communities because principles are derailed. The continuous spirit of delivering value to the end consumers and making a reasonable profit in an ethical way is what businesses should strive to attain. It will sustain the business in its operations and lead to an upward spiral of growth. The word 'commerce' literally means people coming together for business. As such, principles governing these human relationships allow satisfied customers to reciprocate by supporting businesses that enrich their lives by means of good products and services.

\subsection{Conclusion and Direction for Future Research}

Nations rise and fall, so do business empires. While the idea of perpetual existence as a business is wonderful, many will likely not survive, let alone thrive. Consider a data from the U.S. Bureau of Labor Statistics (2017): 50\% of companies fail to cross the 5th year mark since inception and $70 \%$ more fail by the 10 th year. In other words, more than half of companies will eventually fail.

Despite the pessimistic statistics, a business must be born on optimism. Likewise, any attempt to address the challenges of change in the business setting is welcome. This paper proposes a theoretical framework suggesting three changeless cores on which a business should stand. As the paper is theoretical in nature, future research may be directed towards empirical investigations to validate the propositions set forth in this paper. Interested academics and thinkers may also work on the classifications and dimensions of principles and core values in order to come up with possible measurement for the variables.

Suggestion on operationalizing the three pillars include the use of principle-centered leadership survey (Bandsuch et al., 2008; Covey \& Gulledge, 1994), human resource screening (Beard, 2019), and mission statements questionnaire (Fairhurst et al., 1997; Kopaneva, 2019). Care should be taken to validate the psychometric properties of 
these instruments to ensure the feasibility of measurement in the context of business organizations.

\section{References}

Agocs, C. (1997). Institutionalized resistance to organizational change: Denial, inaction and repression. Journal of Business Ethics, 16(9), 917-931.

Aguilar, I. L., Alonso, G. M., Portilla, A. R., \& Hidalgo, A. (2019). Sustainable business models through the lens of organizational design: A systematic literature review. Sustainability, MDPI, Open Access Journal, 11(19), 1-20.

Anser, M. K., Yousaf, Z., Usman, M., Yousaf, S., Fatima, N., Hussain, H., \& Waheed, J. (2020). Strategic business performance through network capability and structural flexibility. Management Decision.

Arvey, R. D., Dewhirst, H. D., \& Boling, J. C. (1976). Relationships between goal clarity, participation in goal setting, and personality characteristics on job satisfaction in a scientific organization. Journal of Applied Psychology, 61(1), 103.

Bandsuch, M., Pate, L., \& Thies, J. (2008). Rebuilding stakeholder trust in business: An examination of principlelcentered leadership and organizational transparency in corporate governance. Business and Society Review, 113(1), 99-127.

Barrick, C. (2017). Get the right people on the bus, part 1: Recruiting quality faculty. The Department Chair, 27(3), 9-11.

Beard, B. D. (2019). An investigation of Jim Collins's Good to Great and applications for rural school districts and their leaders. Unpublished doctoral dissertation, University of Missouri, Columbia.

Beauchamp, M. R., McEwan, D., \& Waldhauser, K. J. (2017). Team building: Conceptual, methodological, and applied considerations. Current opinion in psychology, 16, 114-117.

Bolland, E. (2017). People, mission, vision and planning in strategic management. Comprehensive Strategic Management, Emerald Publishing Limited, 57-85.

Bracha, H. S., Ralston, T. C., Matsukawa, J. M., Williams, A. E., \& Bracha, A. S. (2004). Does "fight or flight" need updating? Psychosomatics, 45(5), 448-449.

Bratianu, C., \& Balanescu, G. V. (2008). Vision, mission and corporate values: A comparative analysis of the top 50 US companies. Management \& Marketing, 3(3), 19-38.

Campbell, A., \& Yeung, S. (1991). Brief case: Mission, vision and strategic intent. Long Range Planning, 24(4), 145-147.

Cenamor, J., Parida, V., \& Wincent, J. (2019). "How entrepreneurial SMEs compete through digital platforms: The roles of digital platform capability, network capability and ambidexterity". Journal of Business Research, 100, 196-206. 
Collins, J. (2011). Good to great: Why some companies make the leap and others don't (1st ed.). New York: Harper Business.

Collins, J. (2006). Level 5 leadership: The triumph of humility and fierce resolve. Harvard Business Review, 83(7), 136-143.

Cosenz, F., Rodrigues, V. P., \& Rosati, F. (2020). Dynamic business modeling for sustainability: Exploring a system dynamics perspective to develop sustainable business models. Business Strategy and the Environment, 29(2), 651-664.

Covey, S. R. (1992). The seven habits of highly effective people. London: Simon and Schuster.

Covey, S. R., \& Gulledge, K. A. (1994). Principle-centered leadership and change. The Journal for Quality and Participation, 17(2), 12.

Craven, M., Mysore, M., Singhal, S., \& Wilson, M. (2020). Covid-19: Briefing materials: Global health and crisis response. McKinsey \& Company. Retrieved from https://www.mckinsey.com/ /media/McKinsey/Business\%20Functions/ Risk/Our\%20Insights/COVID\%2019\%20Implications\%20for\%20business/ COVID\%2019\%20April\%2013/COVID-19-Facts-and-Insights-April-24.ashx

Demortain, D. (2012). Enabling global principle@based regulation: The case of risk analysis in the Codex Alimentarius. Regulation \& Governance, 6(2), 207-224.

Dennis, I. (2008). A conceptual enquiry into the concept of a 'principles-based'accounting standard. The British Accounting Review, 40(3), 260-271.

Drucker, P. (2014). Innovation and entrepreneurship. Routledge.

Edgeman, R. L. (1998). Principlelcentered leadership and core value deployment. The TQM Magazine, 10(3), 190-193.

Erdogan, I., Rondi, E., \& De Massis, A. (2020). Managing the tradition and innovation paradox in family firms: A family imprinting perspective. Entrepreneurship Theory and Practice, 44(1), 20-54.

Fairhurst, G. T., Jordan, J. M., \& Neuwirth, K. (1997). Why are we here? Managing the meaning of an organizational mission statement. Journal of Applied Communication Research, 25(4), 243-263.

Finnie, W. C., \& Abraham, S. C. (2002). Getting from good to great: A conversation with Jim Collins. Strategy \& Leadership, 30(5), 10-14.

Fiske, A. P. (1992). The four elementary forms of sociality: framework for a unified theory of social relations. Psychological review, 99(4), 689.

Floyd, K., Freling, R., Alhoqail, S., Cho, H. Y., \& Freling, T. (2014). How online product reviews affect retail sales: A meta-analysis. Journal of Retailing, 90(2), 217-232.

Gholami, H., Zakuan, N., Saman, M. Z. M., Sharif, S., \& Kohar, U. H. A. (2020). Conceptualizing and operationalizing the student relationship management strategy: Towards a more sustainable-based platform. Journal of Cleaner Production, 244, 118707.

Gottdiener, M. (2020). The theming of America: American dreams, media fantasies, and themed environments. Routledge. 
Hadj, T. B. (2020). Effects of corporate social responsibility towards stakeholders and environmental management on responsible innovation and competitiveness. Journal of Cleaner Production, 250, 119490.

Harari, Y. N. (2020). The world after coronavirus. Financial Times, 20.

Holloman Jr, H. L., Rouse Jr, W. A., \& Farrington, V. (2007). PurposeØdriven leadership: Defining, defending and sustaining a school's purpose. International Journal of Leadership in Education, 10(4), 437-443.

Hong, H. Y., \& Sullivan, F. R. (2009). Towards an idea-centered, principle-based design approach to support learning as knowledge creation. Educational Technology Research and Development, 57(5), 613.

Joachim, A. (2010). Interface between corporate vision, mission and production and operations management. Global journal of management and business research, 10(2), 18-23.

Khazanov, D., Medved, A., Young, E. M., \& Holmes, T. (2019). Air Combat: Dogfights of World War II. Bloomsbury Publishing.

Kim, E. Y., Ko, E., Kim, H., \& Koh, C. E. (2008), “Comparison of benefits of radio frequency identification: Implications for strategic business performance in the US and Korean retailers". Industrial Marketing Management, 37(7), 797-806.

Knapp, S., \& VandeCreek, L. (2007). Balancing respect for autonomy with competing values with the use of principle-based ethics. Psychotherapy: Theory, Research, Practice, Training, 44(4), 397.

Kopaneva, I. M. (2019). Left in the dust: Employee constructions of mission and vision ownership. International Journal of Business Communication, 56(1), 122-145.

Lunenburg, F. C. (2011). Goal-setting theory of motivation. International Journal of Management, Business, and Administration, 15(1), 1-6.

Missimer, M., Robèrt, K. H., \& Broman, G. (2017). A strategic approach to social sustainability-Part 2: A principle-based definition. Journal of cleaner production, 140, 42-52.

Papulova, Z. (2014). The significance of vision and mission development for enterprises in Slovak Republic. Journal of Economics, Business and management, 2(1), 1216.

Partanen, J., Kohtamäki, M., Patel, P. C., \& Parida, V. (2019). "Supply chain ambidexterity and manufacturing SME performance: The moderating roles of network capability and strategic information flow". International Journal of Production Economics, 221, 107470.

Pfeffer, J., \& Veiga, J. F. (1999). Putting people first for organizational success. Academy of Management Perspectives, 13(2), 37-48.

Reddy, K., \& Sharma, U. (2014). Institutional antecedents of principle-based corporate governance practices: A case study of publicly listed companies in Fiji. Journal of Accounting \& Organizational Change, 10(1), 49-82.

Reid III, W. (2017). Service and humility in leadership: Intriguing theories, but do they actually produce results? Servant Leadership: Theory \& Practice, 4(2), 13. 
Rudani, R. B. (2020). Principles of management. McGraw-Hill Education.

Russell, S., \& Brannan, M. J. (2016). "Getting the right people on the bus": Recruitment, selection and integration for the branded organization. European Management Journal, 34(2), 114-124.

San Juan, D. M. (2020). Responding to COVID-19 Through Socialist (ic) Measures: A Preliminary Review. Available at SSRN 3559398.

Shim, W., \& Lee, S-W . (2019). An agile approach for managing requirements change to improve learning and adaptability. Journal of Industrial Information Integration, 14(1), 16-23.

Skyrme, D. J. (1994). Flexible working: Building a lean and responsive organization. Long Range Planning, 27(5), 98-110.

Stewart, A. M., Mullarkey, G. W., \& Craig, J. L. (2003). Innovation or multiple copies of the same lottery ticket: The effect of widely shared knowledge on organizational adaptability. Journal of Marketing Theory and Practice, 11(3), 25-45.

Sun, X., Cao, Y., Li, S., \& Li, X. (2017). Building a global responsive organization: The case of the Haier group. In the Responsive Global Organization, New insights from global strategy and international business (pp. 149-168). Emerald Publishing Limited.

Taiwo, A. A., Lawal, F. A., \& Agwu, E. (2016). Vision and mission in organization: Myth or heuristic device? The International Journal of Business \& Management, 4(3).

Tallon, P. P., \& Pinsonneault, A. (2011). Competing perspectives on the link between strategic information technology alignment and organizational agility: Insights from a mediation model. MIS Quarterly, 463-486.

Thakur, R., \& Srivastava, S. (2018). From resistance to readiness: The role of mediating variables. Journal of Organizational Change Management, 31(2), 230-247.

United States Department of Labor. (2017). Survival of private sector establishments by opening year. Retrieved from https://www.bls.gov/bdm/us_age_naics_00_ table7.txt

Wells, A. (2014). Agile management: Strategies for success in rapidly changing timesan Australian University Library perspective. IFLA journal, 40(1), 30-34.

Wells, M. J. (2011). Framework-based approach to teaching principle-based accounting standards. Accounting Education, 20(4), 303-316.

Yang, Y., Gong, Y., Land, L. P. W., \& Chesney, T. (2020). Understanding the effects of physical experience and information integration on consumer use of online to offline commerce. International Journal of Information Management, 51(1), 102046.

Zhang, K., \& Liu, Z. (2020). An Investigation on Fair Trade Business: Opportunities and Challenges. In Supply Chain and Logistics Management: Concepts, Methodologies, Tools, and Applications (pp. 1205-1227). IGI Global. 